OPEN ACCESS

Edited by:

Federico Benetti,

Scuola Internazionale di Studi

Superiori Avanzati, Italy

Reviewed by:

Alberto Granzotto,

Centro Scienze dell'Invecchiamento e

Medicina Traslazionale, Italy

Maria Elena Ferrero,

Università degli Studi di Milano, Italy

*Correspondence:

Simon C. Drew

sdrew@unimelb.edu.au

Specialty section:

This article was submitted to

Neurodegeneration,

a section of the journal

Frontiers in Neuroscience

Received: 08 December 2016

Accepted: 18 May 2017

Published: 02 June 2017

Citation:

Drew SC (2017) The Case for Abandoning Therapeutic Chelation of Copper lons in Alzheimer's Disease.

Front. Neurosci. 11:317.

doi: 10.3389/fnins.2017.00317

\section{The Case for Abandoning Therapeutic Chelation of Copper Ions in Alzheimer's Disease}

\author{
Simon C. Drew* \\ Department of Medicine, Royal Melbourne Hospital, University of Melbourne, Melbourne, VIC, Australia
}

The "therapeutic chelation" approach to treating Alzheimer's disease (AD) evolved from the metals hypothesis, with the premise that small molecules can be designed to prevent transition metal-induced amyloid deposition and oxidative stress within the AD brain. Over more than 20 years, countless in vitro studies have been devoted to characterizing metal binding, its effect on $A \beta$ aggregation, ROS production, and in vitro toxicity. Despite a lack of evidence for any clinical benefit, the conjecture that therapeutic chelation is an effective approach for treating $A D$ remains widespread. Here, the author plays the devil's advocate, questioning the experimental evidence, the dogma, and the value of therapeutic chelation, with a major focus on copper ions.

Keywords: Alzheimer's disease, $\beta$-amyloid, copper, bioinorganic chemistry, $\mathrm{N}$-truncation, chelator, metals hypothesis, metal homeostasis

\section{INTRODUCTION}

The "amyloid cascade hypothesis" of Alzheimer's disease (AD) proposes disease is caused by accumulation of the $\beta$-amyloid (A $\beta$ ) peptide (typically up to 42 residues in length) that is proteolytically derived from the amyloid precursor protein (APP; Hardy and Higgins, 1992; Masters and Selkoe, 2012). Consistent with the structure of the plaque core and congophilic angiopathy observed in post-mortem $A D$ brain, synthetic $A \beta_{1-x}(x=28-43)$ peptides have a propensity to adopt $\beta$-sheet structure in aqueous solution in the $\mathrm{pH}$ range 4-7 (Barrow and Zagorski, 1991). $\mathrm{A} \beta_{1-\mathrm{x}}$ elicits both neurotrophic and neurotoxic actions (Whitson et al., 1989; Yankner et al., 1990; Collins et al., 2015). Despite some potential experimental artifacts (Watt et al., 2013; Welzel et al., 2014) and some good arguments that the link between $\mathrm{A} \beta$ and $\mathrm{AD}$ is indirect (Herrup, 2015), soluble $A \beta$ oligomers are widely viewed as toxic intermediates responsible for $A D$ pathology (McLean et al., 1999; Selkoe, 2008) and sporadic AD has been associated with an inefficient clearance of $A \beta$ from the central nervous system (Mawuenyega et al., 2010).

The "metals hypothesis of $\mathrm{AD}$ " argues that accumulation of $\mathrm{A} \beta$ is insufficient to explain the onset of $\mathrm{AD}$ and that dysregulation of the brain's intrinsic supply of metal ions, notably copper, zinc, and iron, creates a "rogue" form of $A \beta$ that promotes aggregation and, in the case of copper and iron, generates reactive oxygen species (ROS) that drive disease (Bush et al., 1994a; Bush, 2000, 2003, 2008; Bush and Tanzi, 2008; Duce et al., 2011).

From the perspective of the bioinorganic chemist, the past decade has led to a reasonable consensus regarding the coordination chemistry, thermodynamic stability and in vitro mechanism of ROS production by copper and A $\beta$ (Drew and Barnham, 2011; Faller et al., 2014; Reybier et al., 2016). Despite this detailed knowledge, no therapeutic has been designed that specifically takes advantage of this structural information, although a large number of chelators and oligopeptides have been proposed (reviewed in Telpoukhovskaia and Orvig, 2013). Perhaps, then, it is not 
surprising that clinical trials of metal chelators have suffered the same set-backs as anti-amyloid therapies. While this may reflect an inappropriate choice of chelator, it also raises the question as to the validity of the underlying hypothesis, especially given the number of controversial findings over the past 20 years. Some examples include the assertions that: $A \beta$ possesses a superoxide dismutase-like di-copper binding site (Curtain et al., 2001; Tickler et al., 2005; Smith et al., 2006); A $\beta$ generates ROS in the absence of metal ions (Hensley et al., 1994; Turnbull et al., 2001); Met35 reduces $\mathrm{Cu}^{2+}(\mathrm{A} \beta)$ to an air-stable $\mathrm{Cu}^{+}(\mathrm{A} \beta)$ complex (Barnham et al., 2003a; Ciccotosto et al., 2004); $\mathrm{Cu}^{2+}$ cannot displace $\mathrm{Zn}^{2+}$ from $\mathrm{A} \beta_{1-40}$ (Bush et al., 1994b); the affinity of $\mathrm{A} \beta_{1-42}$ for $\mathrm{Cu}^{2+}$ is 10 attomolar, seven orders of magnitude higher than that of $A \beta_{1-40}$ (Atwood et al., 2000); rat and mouse $A \beta$ bind $\mathrm{Cu}^{2+}$ much less avidly than human $A \beta$ (Bush et al., 1994a; Atwood et al., 1998; Eury et al., 2011); A $\beta$ does not aggregate in the absence of metal ions (Atwood et al., 2000; Bush and Tanzi, 2002); A $\beta$ plaques are "galvanized" (Bush and Tanzi, 2002); ${ }^{1}$ and that a 22-residue domain within APP has biological ferroxidase activity modulated by $\mathrm{Zn}^{2+}$ binding (Duce et al., 2010; Ebrahimi et al., 2012, 2013).

The above examples aside, there has also been a change in focus in recent years from metal ion interaction with $A \beta$ as a driver of aggregation and toxicity to a more general picture of global metal ion dysregulation, in which direct metal-A $\beta$ interactions play a secondary or even inconsequential role (White et al., 2006; James et al., 2012; Singh et al., 2013). In other instances, there has been a synthesis of the two schools of thought, whereby an accumulation of metal ions in amyloid plaques is proposed to be responsible for the loss of normal metal ion balance (Hung et al., 2011; Ceccom et al., 2012; Roberts et al., 2012; Ayton et al., 2013). With respect to copper ions, some propose that $\mathrm{AD}$ is a disease of dietary copper deficiency (Klevay, 2008), while others propose it is caused by excess inorganic copper in the diet that can be treated using zinc therapy (Hoogenraad, 2011; Brewer, 2014) or a low-copper diet (Squitti et al., 2014b). Soluble, monomeric $A \beta_{1-x}$ has even been proposed to possess a normal function in metal export, whereby metal-enrichment within plaques is associated with a loss of function (Kepp, 2016). Other potential physiological functions of $A \beta_{1-40 / 42}$ have been proposed, as an antimicrobial peptide (Soscia et al., 2010; Kumar et al., 2016) and as a cerebrovascular sealant (Atwood et al., 2003), although any role for copper ions in these contexts remains to be established.

\section{IS BIOLOGICAL A $\beta$ METAL BINDING FEASIBLE?}

Four common arguments made in favor of the biological/disease relevance of metal-A $\beta$ interactions are (i) the release of "high" concentrations of copper and zinc ions in the synaptic cleft upon depolarization, 15-250 $\mu \mathrm{M}$ in the case copper (Kardos et al., 1989; Hartter and Barnea, 1998); (ii) $\mathrm{Zn}^{2+}, \mathrm{Cu}^{2+}$, and

\footnotetext{
${ }^{1}$ Whilst making for a memorable title, "The galvanization of $\beta$-amyloid...", implies a non-physiological two-electron reduction of $\mathrm{Zn}^{2+}$ (aq) to $\mathrm{Zn}(\mathrm{s})\left(E^{0}=-0.76 \mathrm{~V}\right.$ vs. SHE).
}

$\mathrm{Fe}^{3+}$-induced aggregation of synthetic $\mathrm{A} \beta$ (Atwood et al., 1998; Cherny et al., 1999), (iii) elevated concentrations of $A \beta$ within the $\mathrm{AD}$ cortex as compared with unaffected individuals (Lue et al., 1999); and (iv) a "high" affinity of human $\mathrm{A} \beta$ for $\mathrm{Cu}^{2+}$. The apparent dissociation constant of $\mathrm{A} \beta_{1-\mathrm{x}}(\mathrm{x} \geq 16)$ at $\mathrm{pH} 7$ is $\sim 0.1 \mathrm{nM}$ (Alies et al., 2013; Young et al., 2014) and thus better described as "moderate," since other metal-binding species with comparable (or higher) capacity to bind $\mathrm{Cu}^{2+}$ are also present in the central nervous system (CNS). For example, glutamate also reaches transiently high local concentration during synaptic signaling (Danbolt, 2001), making it competitive at relevant physiological concentrations (Frączyk et al., 2016), while other neurotransmitters such as histamine (HA) have even higher $\mathrm{Cu}^{2+}$ affinity than glutamate (Dawson et al., 1990). Aside from one study concluding $A \beta_{1-42}$ oligomers have an enhanced affinity $\left(K_{\mathrm{d}}<3\right.$ pM in HEPES pH 7.4; Jiang et al., 2013) that enables them to compete with human serum albumin (HSA), the latter has also been proposed as a major competitor with $A \beta$ for copper ions within the CNS (Rózga and Bal, 2010), effectively competing for $99.9 \%$ of $\mathrm{Cu}^{2+}$ (Perrone et al., 2010) and binding $\mathrm{Cu}^{+}$stronger than $\mathrm{A} \beta$ (Lu et al., 2015). Metallothioneins (MTs) are likely competitors for extracellular $\mathrm{Cu}^{2+}$ in the CNS (Meloni et al., 2008; Chung et al., 2010). Moreover, the endoproteolytic cleavage product $A \beta_{4-x}$, which is also present in healthy cortex (see below), has very high affinity (Mital et al., 2015) and can even retain $\mathrm{Cu}^{2+}$ in competition with MTs (Wezynfeld et al., 2016).

The pecking order, even among this limited selection of $\mathrm{Cu}^{2+}$ binding species, is therefore likely $\mathrm{A} \beta_{4-\mathrm{x}} \geq \mathrm{MTs}>\mathrm{HSA}$ $>$ Glu, HA $>A \beta_{1-x}$. To explain why $A \beta_{1-x}$ interacts with synaptic $\mathrm{Cu}^{2+}$ only in disease, one must therefore argue that there exists an underlying imbalance that creates abnormalities in the regulation of metal-binding amino acids, peptides and proteins. For example, the concept of the "labile copper pool" has been introduced (James et al., 2012). This places metal-A $\beta_{1-x}$ interactions downstream of an underlying pathology, making this modest-affinity, non-specific binding non-central to disease pathogenesis. The non-specificity argues that a range of other proteins and peptides could also adopt unwanted, modest-affinity (and potentially redox-active) $\mathrm{Cu}^{2+}$ coordination, making the strong focus on $\mathrm{A} \beta_{1-\mathrm{x}}$ unwarranted.

In vitro evidence for the ability of $\mathrm{A} \beta_{1-\mathrm{x}}$ to generate ROS in the presence of $\mathrm{Cu}^{2+}$ and biological reducing agents was quickly established (Huang et al., 1999; Opazo et al., 2002) although continues to be debated (Mayes et al., 2014; Pedersen et al., 2016; Reybier et al., 2016), while the underlying coordination chemistry has largely been unraveled (Drew and Barnham, 2011; Faller et al., 2014). A greater degree of $\mathrm{H}_{2} \mathrm{O}_{2}$ production was reported for $\mathrm{Cu}^{2+}$ and $\mathrm{Fe}^{3+}$ in the presence of human $\mathrm{A} \beta_{1-\mathrm{x}}$ vs. rat/mouse $\mathrm{A} \beta_{1-\mathrm{x}}$ (Huang et al., 1999; Barnham et al., 2003a), which was concluded to be consistent with an absence of amyloid pathology in these animals. Although the latter is a common argument made in support of the metals hypothesis (Bush et al., 1994b; Atwood et al., 1998; Huang et al., 1999; Barnham et al., 2003a), aged rats can exhibit neuritic plaques (Vaughan and Peters, 1981) and a number of AD-related functional, morphological and behavioral changes are observed in wild type rats and mice if clearance of murine $A \beta$ is impaired by the pharmacological 
inhibition or genetic ablation of $A \beta$ degrading/clearing enzymes such as neprilysin (NEP) and ATP-binding cassette C1 (Iwata et al., 2000; Madani et al., 2006; Krohn et al., 2015). Since human and murine $A \beta$ adopt rather different $\mathrm{Cu}^{2+}$ coordination (Eury et al., 2011), this argues against a specific role for direct $\mathrm{Cu}-$ $A \beta$ interaction and instead reinforces the importance of $A \beta$ clearance.

While exogenous application of $A \beta$ to cultured cells appears capable of causing oxidative damage that can be prevented by metal chelators or antioxidants (Behl et al., 1992, 1994; Manelli and Puttfarcken, 1995; Rosales-Corral et al., 2012), distinguishing direct metal- $\mathrm{A} \beta$ redox cycling from downstream oxidative damage and cell dysfunction is not straightforward. Similar caveats apply to reports that metal chelators inhibit $\beta$ amyloid accumulation in transgenic mice (Cherny et al., 1999), since the chelator may bind metal ions released downstream of cellular events triggered by the apo-peptide. To "potentiate" the toxicity of $\mathrm{A} \beta$, it is common to co-administer $\mathrm{Cu}^{2+}$ with $\mathrm{A} \beta$ to cultured cells (Smith et al., 2006; Sarell et al., 2010), frequently at relatively high steady-state concentrations up to $40 \mu \mathrm{M}$ (Meloni et al., 2008; Chung et al., 2010; Perrone et al., 2010). Despite the corresponding $\mathrm{Cu}^{2+}$ alone being generally tolerable in such cell culture systems, a "double insult" cannot be ruled out, whereby $\mathrm{Cu}^{2+}$ compounds upstream stress caused by $\mathrm{A} \beta$ in isolation. The non-specific nature of this mechanism of "potentiating" toxicity of $A \beta$ is demonstrated by the fact that similar results can be achieved by co-administering $\mathrm{Fe}^{3+}$ and $\mathrm{A} \beta$ to cultured neurons (Schubert and Chevion, 1995; Rottkamp et al., 2001), yet $A \beta$ has an extremely low affinity for $\mathrm{Fe}^{3+}$ (Valensin et al., 2011), making $\mathrm{Fe}(\mathrm{A} \beta)$ redox cycling unlikely.

In order to demonstrate direct binding of $\mathrm{Cu}^{2+}$ to $\mathrm{A} \beta$ within senile plaque cores, brain amyloid extractions (Selkoe et al., 1986; DeWitt et al., 1998) have been subjected to Raman spectroscopic analysis (Dong et al., 2003). Using prior Raman investigations of metal binding to synthetic $\mathrm{A} \beta$ (Miura et al., 2000) as a guide, Dong et al. (2003) concluded that $\mathrm{Cu}^{2+}$ (and $\mathrm{Zn}^{2+}$ ) were directly bound to $A \beta$ in plaques, based upon intensity changes assigned to metal ion coordination to His side chains. Whilst highly suggestive of direct $\mathrm{Cu}^{2+}-\mathrm{A} \beta$ binding, the actual composition of those senile plaque extracts is not known, nor is the true origin of metal ions they contain. Purity of amyloid cores was estimated as $>90 \%$ based upon Congo red birefringence (Dong et al., 2003), with further evidence of purity including the inability to observe a Raman band due to $\operatorname{Trp}(\mathrm{A} \beta$ contains no $\operatorname{Trp}$ ). Given the possibility of up to $10 \%$ impurities and the fact that $\operatorname{Trp}$ is the lowest frequency amino acid observed in vertebrates, one simple explanation for the $\mathrm{Cu}^{2+}$-His Raman bands is that they derive from non-amyloid components. Regardless of the limitations in final purity by this method (Rostagno and Ghiso, 2009), disruption of native metal binding sites, for example by treatment of crude brain homogenates by denaturation at $97^{\circ} \mathrm{C}$ and $3 \mathrm{mM}$ sodium azide (DeWitt et al., 1998; Dong et al., 2003), may still lead to the release of metal ions from the many hundreds of proteins that are also found within senile plaques (Drummond et al., 2017), ultimately resulting in adventitious binding to $A \beta$ prior to pelleting and subsequent fractionation.

As mentioned above, $\mathrm{N}$-truncation of $\mathrm{A} \beta$ can greatly enhance its $\mathrm{Cu}^{2+}$ binding affinity. Following the seminal sequencing of brain amyloid (Glenner and Wong, 1984), subsequent studies identified a large degree of heterogeneity at the $\mathrm{N}$-terminus, with a predominance of the $A \beta_{4-x}$ isoform in amyloid derived from subjects with AD, Down Syndrome and cerebral amyloid angiopathy (Masters et al., 1985a,b). Nevertheless, most effort has been invested in measuring and modulating levels of $A \beta_{1-40 / 42}$ in the CNS as AD biomarkers (Blennow et al., 2015) and therapies (Wisniewski and Goñi, 2014; Ingelsson and Lannfelt, 2016), respectively. With hindsight, the field's dismissal of the "ragged" $\mathrm{N}$-termini appears to stem from a perception that this was, at least for $A \beta_{4-x}$, an artifact of pepsin digestion during the plaque extraction (Masters and Selkoe, 2012). A number of observations argue against this, however; $A \beta_{4-x}$ is also detected in collagenase digests of senile plaque cores (Miller et al., 1993), in undigested amyloid extractions (Näslund et al., 1994; Sergeant et al., 2003), and in $\mathrm{A} \beta$ immunoprecipitated from post mortem brain (Lewis et al., 2006; Portelius et al., 2010). Since the initial report of $>60 \%$ $\mathrm{A} \beta_{4-\mathrm{x}}$ in the amyloid plaque cores within the cortex of selected $\mathrm{AD}$ brain samples (Masters et al., 1985b), others surveyed $\mathrm{A} \beta_{4-\mathrm{x}}$ levels in larger cohorts. Näslund et al. (1994) reported lower levels of $A \beta_{4-x}$ as compared with $A \beta_{1-x}$ and pyrogluamate $\mathrm{A} \beta_{11-\mathrm{x}}$, but $\mathrm{A} \beta_{4-\mathrm{x}}$ remained consistently detected in both $\mathrm{AD}$ and unaffected individuals. Sergeant et al. (2003) also concluded amino-truncated isoforms represented more than $60 \%$ of all $A \beta$ species in advanced $\mathrm{AD}$ and in non-demented individuals with amyloid, with comparable $A \beta_{1-x}$ and $A \beta_{4-x}$ levels. Lewis et al. (2006) reported that $\mathrm{A} \beta_{4-42}$ was the most dominant peak in mass spectrometry analyses of $\mathrm{AD}$ and vascular dementia samples. Mass spectrometry analyses of Portelius et al. (2010) supported this conclusion and further reported that $\mathrm{A} \beta_{4-42}$ and $\mathrm{A} \beta_{1-42}$ are dominant isoforms in the hippocampus and cortex of sporadic $\mathrm{AD}$ patients, as well as in the cortex of healthy controls. In fact, cortical $\mathrm{A} \beta_{4-42}$ levels are comparable in $\mathrm{AD}$ and healthy control and are much greater in the hippocampus in $\mathrm{AD}$ vs. control (Portelius et al., 2010).

Of the $\mathrm{Zn}$-dependent endopeptidases so far identified as $A \beta$ degrading enzymes (Saido and Leissring, 2012; Jha et al., 2015), neprilysin (NEP; Howell et al., 1995; Kanemitsu et al., 2003) and insulin degrading enzyme (IDE; Morelli et al., 2004; Grasso et al., 2011) appear capable of cleaving the Glu3-Phe4 bond to generate $A \beta_{4-x}$ in vitro. An inverse correlation has been established between NEP levels and/or activity with brain $A \beta$ levels in aging (Russo et al., 2005) and AD (Yasojima et al., 2001; Mohajeri et al., 2002; Hellström-Lindahl et al., 2008; Zhou et al., 2013). The apparent increase of $A \beta_{4-42}$ in the hippocampus of $\mathrm{AD}$ subjects might be attributed to reduced endoproteolysis at $\mathrm{C}$ terminal locations within $A \beta$, leading to aggregates of $A \beta_{1-x}$ in which only the amino-terminal Glu3-Phe4 bond is accessible to NEP/IDE.

Synthetic $A \beta_{4-40}$ and $A \beta_{4-42}$ were concluded to be as toxic to cultured primary neurons as $A \beta_{1-42}$ (Bouter et al., 2013) and mice subjected to intracerebroventricular injection of $A \beta_{4-42}$ exhibited memory deficits that could be rescued by passive immunotherapy using antibodies targeting the $\mathrm{N}$-terminus of $\mathrm{A} \beta_{4-\mathrm{x}}$ (Antonios et al., 2015). Transgenic animals expressing human APP do not accumulate the N-truncated $A \beta$ found in human brain (Kalback et al., 2002; Schieb et al., 2011). Transgenic mice specifically expressing and releasing extracellular $A \beta_{4-42}$ 
displayed spatial memory deficits and marked hippocampal neuron loss. However, both of the in vivo models of $\mathrm{A} \beta_{4-42}$ toxicity bypass the physiological pathways of $A \beta_{4-42}$ production (i.e., the $A \beta_{4-42}$ is not endoproteolytically cleaved from APPderived human $\left.\mathrm{A} \beta_{1-42}\right)$. Thus, the models only represent a pathological state induced by overproduction of $A \beta_{4-42}$ and do not permit the study of any possible function $A \beta_{4-x}$.

The reports of $A \beta_{4-x}$ as a major isoform in the $A D$ brain and in the cortex of unaffected individuals have some profound consequences for the metals hypothesis. The N-terminal FRHsequence of $\mathrm{A} \beta_{4-\mathrm{x}}$ endows it with the amino-terminal $\mathrm{Cu}$ and $\mathrm{Ni}$ (ATCUN) motif that creates a $\mathrm{Cu}^{2+}$ binding site with an affinity $\left(K_{\mathrm{d}}=30 \mathrm{fM}\right.$ at $\mathrm{pH} 7.4$ was measured for $\left.\mathrm{A} \beta_{4-16}\right)$ that is comparable to functional cuproproteins (Mital et al., 2015). This makes it more stable than $\mathrm{Cu}\left(\mathrm{A} \beta_{1-\mathrm{x}}\right)$ by more than three orders of magnitude and around 100 times higher than the reported enhancement of $\mathrm{Cu}^{2+}$ binding affinity by $\mathrm{A} \beta_{1-42}$ aggregates $\left(K_{\mathrm{d}}<3\right.$ pM; Jiang et al., 2013). Moreover, $\mathrm{Cu}^{2+}$ coordinated to the high affinity binding site of $\mathrm{A} \beta_{4-\mathrm{x}}$ does not appear to undergo any physiologically accessible $\mathrm{Cu}^{+} / \mathrm{Cu}^{2+}$ redox cycle (Mital et al., 2015; Wiloch et al., 2016). These properties suggest a functional role for $\mathrm{A} \beta_{4-\mathrm{x}}$ that is arguably more plausible than any other proposed for $A \beta_{1-x}$ and copper. With this knowledge in hand, one can look to other ATCUN motifs within the A $\beta$ sequence, since these should also possess high affinity $\mathrm{Cu}^{2+}$ binding sites. The $A \beta_{11-x}$ fragment, created by $\beta^{\prime}$ cleavage, contains His in the third position that, if left unmodified, could bind $\mathrm{Cu}^{2+}$ with comparable affinity to $A \beta_{4-x}$ (Barritt and Viles, 2015). It will probably not do so in vivo, however, since its $\mathrm{N}$-terminus is cyclized to the pyroglutamate form (Näslund et al., 1994) that destroys the ATCUN motif. Another ATCUN sequence is present in $A \beta_{12-x}$, which was identified in neurofibrillary amyloid (Masters et al., 1985a), but has since received little attention.

In summary, Raman spectroscopic evidence for $\mathrm{Cu}^{2+}$-His coordination within senile plaque extracts is highly suggestive of direct $\mathrm{Cu}^{2+}-\mathrm{A} \beta$ binding, although further evidence for the purity of the isolated senile plaque cores and the origin of metal ions is warranted. Cell culture models suggest that coadministration of copper ions enhances toxicity of exogenous, synthetic $A \beta_{1-40 / 42}$, yet it remains inconclusive whether this results from direct copper-A $\beta_{1-x}$ binding and/or whether the conditions employed are representative of those at a synapse. The $\mathrm{A} \beta_{4-\mathrm{x}}$ isoform produced by endoproteolytic processing of $A \beta_{1-x}$ presents the possibility for a 3,000-fold higher affinity $\mathrm{Cu}^{2+}$ binding as compared with $\mathrm{A} \beta_{1-\mathrm{x}}$ and in a manner that does not produce ROS.

\section{IS THERE MISLOCALIZED COPPER IN THE AD BRAIN?}

The meta-analysis conducted by Schrag et al. (2011) identified a citation bias in the reporting of metal levels in the brain in $\mathrm{AD}$. Despite the large heterogeneity in the published data, they noted that "this bias was particularly prominent among narrative review articles" and further identified problems with a number of studies. In particular, they noted the report by Markesbery and co-workers (Lovell et al., 1998) was discordant with other studies yet "is the most cited paper on the subject of copper in $\mathrm{AD}$ and appears to be the source for numerous articles reporting that copper levels are (several fold) increased in AD" (Schrag et al., 2011). It was also discordant with Markesbery and coworkers' earlier study that reported a significant decrease in copper in AD hippocampus and amygdala (Deibel et al., 1996). Upon exclusion of all studies with methodological shortcomings, the meta-analysis of Schrag et al. (2011) indicated that there was no change in neocortical iron and a significant decrease in neocortical copper in $\mathrm{AD}$ as compared with age-matched control tissue.

Since the influential publication of Lovell et al. (1998), contrasting conclusions have been drawn regarding the relationship between copper and AD. Singh et al. (2013) demonstrated a relationship between increased copper levels in brain capillaries and reduced $A \beta$ clearance across the bloodbrain barrier (BBB) in normal mice. An X-ray fluorescence (XRF) microscopy study of tissue from two neuropathologically confirmed cases of AD reported "hot-spots" with colocalization of copper and zinc with regions of thioflavin-reactive amyloid (Miller et al., 2006). James et al. (2012) "found no difference in the $\mathrm{Cu}$ content of $\mathrm{AD}$ samples relative to healthy tissues," but instead "an increase in the labile pool" of copper within the $\mathrm{AD}$ cortex, which they attributed to "a global distortion of brain $\mathrm{Cu}$ metabolism in $\mathrm{AD}$, distinct from the formation of insoluble $\mathrm{Cu}-\mathrm{A} \beta$ ” Increased labile copper outside the CNS has also been reported (Squitti et al., 2014a) with increased concentrations of labile (non-ceruoplasmin) $\mathrm{Cu}^{2+}$ in serum as a predictor of transitioning from mild cognitive impairment to AD (Squitti, 2014). Rembach et al. (2013) concluded that the previously reported decrease in neocortical copper in $\mathrm{AD}$ (Schrag et al., 2011) could be attributed to a reduction in content harbored within soluble extractable tissue from $\mathrm{AD}$ frontal cortex.

Animal models have not provided any clear evidence for copper imbalance. The copper in plaques of $\mathrm{AD}$ transgenic mice, quantified by XRF microscopy, appears consistent with that of the surrounding neuropil after accounting for local tissue density (James et al., 2017). Leskovjan et al. (2009) argued that failure to observe increased levels of $\mathrm{Cu}$ in plaques within APP transgenic mouse models of $\mathrm{AD}$ is due to inadequate time for plaques to "sink" this metal within their shorter lifespan and that this is consistent with the absence of neurodegeneration in those models (Bourassa and Miller, 2012). While there appears to be a relationship between copper and APP, the variability between transgenic animal models expressing human APP likely makes them unsuitable for elucidating the association (White et al., 1999; Maynard et al., 2002; Bayer and Multhaup, 2005; Wang et al., 2012; Singh et al., 2013) and similar limitations may also apply to copper and $A \beta$.

While Szabo et al. (2015) measured no difference in copper levels in the frontal cortex of control and $\mathrm{AD}$ subjects, the authors did not rule out the possibility of differences in its cellular localization and chemical speciation. In a similar vein, Bush and coworkers have asserted that "metals both accumulate 
in microscopic proteinopathies, and can be deficient in cells or cellular compartments. Therefore, bulk measurement of metal content in brain tissue samples reveal only the "tip of the iceberg," with most of the important changes occurring on a microscopic and biochemical level" (Barnham and Bush, 2014). They further argue that " $\mathrm{Zn}$ and $\mathrm{Cu}$ are sequestered into plaques, whereas intraneurally these metals are depleted" (Ayton et al., 2013).

The evidence to support an intracellular depletion of copper and zinc in $\mathrm{AD}$ remains unclear, although the genesis for this idea appears to have emanated from (i) studies demonstrating that APP overexpression causes copper efflux and intracellular depletion (Treiber et al., 2004; Bayer and Multhaup, 2005), and (ii) the large reported ionophore action the 8-hydroxyquinoline (8HQ)-based compounds 5chloro-7-iodo-8-hydroxyquinoline (CQ; Treiber et al., 2004; White et al., 2006; Crouch et al., 2009), and 5,7-dichloro-2[(dimethylamino)methyl]-8-hydroxyquinoline (PBT2), (Adlard et al., 2008, 2011; Crouch et al., 2009, 2011), resulting in dramatic increases in intracellular copper and zinc. In yeast models, an approximate 100-fold increase in intracellular copper levels was reported in response to combined $\mathrm{CQ} / \mathrm{Cu}^{2+}$ treatment, as compared with a $\sim 10$-fold increase following exogenous addition of $\mathrm{Cu}^{2+}$ alone (Treiber et al., 2004). These observations were recapitulated in other cell models ( $\mathrm{CHO}$ and $\mathrm{N} 2 \mathrm{a}$ cells expressing APP), again with a 100-fold increase in intracellular copper concentration as compared with basal levels when 10 $\mu \mathrm{M} \mathrm{Cu}^{2+} / \mathrm{CQ}$ was added to culture media, and 10-fold increases in zinc and iron in response to exogenous application of their respective CQ complexes (White et al., 2006).

Given the magnitude of the reported ionophore effect, one might expect a 100-fold increase in intracellular copper levels to place significant stress on cultured cells, especially since other significant cellular events such as neuronal differentiation result in only a 2 - to 3 -fold increase in copper (no change in iron, manganese, zinc; Ogra et al., 2016). In studies of CQ, the authors concluded there was "no evidence of increased cell death after $6 \mathrm{~h}$ of exposure to CQ and metals" (White et al., 2006), although no dose response curve monitoring functional changes (e.g., cell metabolism, caspase activation, direct measures of ROS production) was presented in order to substantiate this. Subsequent studies using the SH-SY5Y neuroblastoma cell line again demonstrated dramatic metal influx in response to treatment with CQ (Crouch et al., 2009, 2011) and also PBT2 (Crouch et al., 2011), an effect that also resulted in greater phosphorylated GSK-3 $\beta$ (pGSK3 $\beta$ ). No dose response curves were provided in either of these studies to determine whether the applied concentrations of the 8HQs were toxic. Moreover, there is no reason to assume that basal intracellular metal levels in these cell lines represent a phenotype of copper depletion, since metal levels were reported only as a percentage increase relative to untreated cells (White et al., 2006; Crouch et al., $2009,2011)$. An increase in pGSK3 $\beta$ following treatment with this compound may therefore be part of an apoptotic signaling cascade rather than promoting cell survival (Jacobs et al., 2012). Indeed, studies using a homologous terdentate $8 \mathrm{HQ}$ resulted in a significant increase in pGSK $3 \beta$ only at cytotoxic concentrations (Haigh et al., 2016). In this regard, it is noteworthy that Adlard et al. (2011) did perform a dose response and used 100-fold lower PBT2 concentrations, in which case no signaling cascade involving GSK3 phosphorylation was reported.

In summary, there remains a pervasive belief that copper levels are many-fold higher in AD. Some authors have replaced this picture with one incorporating an increase of extracellular/intracellular copper ratio, although this appears to be motivated by reports of ionophore action of certain chelators, coupled with an underlying presumption that they are effective treatments for $\mathrm{AD}$.

\section{IS THERAPEUTIC CHELATION EFFICACIOUS?}

A large number of metal chelators have been proposed as therapeutics for AD (e.g., Telpoukhovskaia and Orvig, 2013; Robert et al., 2015), while only a handful have been clinically trialed. The most widely promoted therapeutic chelators for AD therapy are CQ (PBT1) and PBT2, both of which are based upon old chemistry with diverse applications (Gholz and Arons, 1964; Stevenson and Freiser, 1967; Rajagopalan et al., 2001; Ding et al., 2005). Terdendate ligands (L) such as PBT2 can bind in a 1:1 $(\mathrm{CuL})$ and a distorted 5-coordinate 1:2 $\left(\mathrm{CuL}_{2}\right)$ form (Kenche et al., 2013), although the predominant $\mathrm{Cu}^{2+}$ bound form of this class of terdentate $8 \mathrm{HQ}$ in a biological context is predicted to be a ternary (mixed-ligand) metal complex involving His side chains of proteins and peptides (Kenche et al., 2013). While $\mathrm{CuL}$ and $\mathrm{CuL}_{2}$ are not capable of generating hydroxyl radicals in the presence of the biological reductant such as ascorbate, the dominant ternary metal complexes can produce as many hydroxyl radicals as $\mathrm{Cu}\left(\mathrm{A} \beta_{1-\mathrm{x}}\right)$ in vitro (Mital et al., 2016) and ROS production can be observed following addition of such $8 \mathrm{HQs}$ to neural stem cell cultures (Haigh et al., 2016). These observations contrast with the founding principle of therapeutic chelation (Barnham and Bush, 2014).

To distinguish bulk chelation therapy, generally associated with systemic removal of heavy metal toxins from the body, therapeutic chelators have been re-branded as "metalprotein attenuating compounds (MPACs)," "ionophores," and "metallochaperones." The use of "MPAC" was popular due to the belief that CQ and PBT2 disaggregated A $\beta$ plaques loaded with $\mathrm{Cu}^{2+}$ and $\mathrm{Zn}^{2+}$ (Cherny et al., 1999; Lannfelt et al., 2008). When large cellular metal uptake was reported in vitro, the term "ionophore" was applied (Treiber et al., 2004; White et al., 2006; Adlard et al., 2008, 2011), while the term "metallochaperone" now tends to be used most often even though the fate of the ligand remains unknown. It is possible $8 \mathrm{HQs}$ behave as carrier ionophores within the hydrophobic lipid environment of various cellular membranes, that copper is not released at all from $8 \mathrm{HQ}$ ligands once localized to a lipid bilayer, and that 8 HQs interfere with native metal binding sites of key regulatory enzymes (Martirosyan et al., 2006; King et al., 2011; Kawamura et al., 2014) due to ternary complex formation.

Studies in mouse models of $\mathrm{AD}$ claimed some promise of therapeutic benefit using $8 \mathrm{HQ}$ therapeutic chelators (Cherny 
et al., 2001; Adlard et al., 2008, 2011). Similar to more conventional therapies targeting $A \beta$, however, the results of therapeutic chelation have been equally disappointing when translated to human clinical trials. As noted by Relkin following the publication of the results from the first phase IIa trial of PBT2 (Relkin, 2008): "The success or failure of PBT2 is predicated on the validity of two controversial hypotheses of $\mathrm{AD}$ pathogenesis. The first is the amyloid hypothesis... [and the] second, and arguably more controversial hypothesis, relates to the role of metal ions in $\mathrm{AD}$. Because many factors affect the accumulation of $A \beta$, whether the attenuation of the interactions of metal ions with $\mathrm{A} \beta$ will be sufficient to alter the course of $\mathrm{AD}$ is uncertain." Previous trials of therapeutic chelation using D-penicillamine provided no evidence of altering clinical progression and was terminated early due to adverse events, leading some to question the scientific rationale for pursuing therapeutic chelation with 8HQs (Squitti et al., 2002). Indeed, independent assessments of the human clinical trials using $8 \mathrm{HQs}$ repeatedly concluded between 2006 through to 2014 that there "is no evidence that MPACs (PBT1 or PBT2) are of benefit in Alzheimer's dementia" (Jenagaratnam and McShane, 2006; Sampson et al., 2008, 2012, 2014).

Despite the above cautions, the conjecture that $8 \mathrm{HQs}$ were effective in treating $\mathrm{AD}$ has been far more prevalent. For example, a post-hoc analysis of the 2008 phase IIa trial stated in its title that "PBT2 Rapidly Improves Cognition in Alzheimer's Disease (Faux et al., 2010)," although it appears this claim pertains to earlier transgenic animal studies rather than the clinical trial in question. In 2013, it was claimed that "clinical trials targeting metal interactions with $A \beta$ have all shown benefit for patients" (Ayton et al., 2013), and even after the release of findings from a repeat phase II trial in April 2014, ${ }^{2}$ some researchers were slow to abandon the mantra that CQ and PBT2 have had "positive clinical outcomes" (Barnham and Bush, 2014) and "significant positive effects on cognition" (Ryan et al., 2015). This most recent trial did not meet its primary endpoint (a reduction of amyloid burden as compared with placebo), echoing previous warnings about "plaques not being the optimal marker of therapeutic success" (Gouras and Beal, 2001). Notwithstanding, all secondary endpoints other than safety and tolerability were also missed (no change in cognition, neuronal function, brain volume or patient function). Tetradentate $8 \mathrm{HQ}$ s with very high $\mathrm{Cu}^{2+}$ affinity have been proposed as alternatives to bi- and terdendtate $8 \mathrm{HQs}$. In non-transgenic mice subjected to intracranial injection of human $\mathrm{A} \beta$, both CQ and a tetradentate 8HQ (apparent $K_{\mathrm{d}}=1.26 \times$ $10^{-18} \mathrm{M}$ for $\mathrm{Cu}^{2+}$ at $\mathrm{pH}$ 7.4) were shown to reverse a loss of contextual fear conditioning which was reasoned to result from the probable extraction of $\mathrm{Cu}^{2+}$ from the injected $\mathrm{A} \beta$ and its "return to the normal circulation of copper ions" (Ceccom et al., 2012). Tetradentate 8 HQs have not progressed to clinical trials.

In summary, there has been a bias toward reporting outcomes of clinical trials of therapeutic copper chelators as positive and beneficial for patients, which drives the continued screening of

${ }^{2}$ www.alzforum.org/news/research-news/pbt2-takes-dive-phase-2-alzheimers-trial (1 April 2014). new chelators in spite of well-defined targets for metal acquisition and release in $\mathrm{AD}$.

\section{CONCLUDING REMARKS}

Therapeutic chelation in its original formulation aimed to deliver a ligand to the CNS in order to prevent copper-induced misfolding and ROS production by $A \beta_{1-x}$, thereby reducing amyloid deposition and oxidative stress within the $\mathrm{AD}$ brain. The concept that metal ion binding to $A \beta$ is responsible for potentiating its toxicity has led to hundreds of in vitro studies devoted to investigating the nature of this binding interaction, the mechanism of ROS production and the effects on $\mathrm{A} \beta$ aggregation. These studies continue unabated, despite convincing in vivo evidence for a direct copper-A $\beta$ interaction or other specific targets for therapeutic chelators, which have so far failed to modify disease outcomes.

The variability in experimental data and their interpretation pertaining to copper speciation and localization has transformed what began as a well-defined objective of inhibiting metal$\mathrm{A} \beta$ interactions into an ill-defined target for therapeutic intervention. A global distortion of copper metabolism in the form of a reduction in copper binding affinity (greater lability) will affect all copper-binding proteins. Hence, it is not clear how the general movement of metal ions, for example from extracellular to intracellular location, will address the underlying cause of the proposed imbalance. Recent first principles calculations taking into account the stochastic nature of copper- $\mathrm{A} \beta$ interactions, transient metal release and reuptake, and the finite volume of a typical synapse, also predict that if soluble $\mathrm{A} \beta$ oligomers are indeed toxic and $\mathrm{Cu}^{2+}$-inducible, then "a partial $\mathrm{Cu}$ (II) depletion [by therapeutic chelation] might actually accelerate rather than eliminate the neurotoxic $\mathrm{A} \beta$ dimer formation" (Goch and Bal, 2017).

If reports about enrichment of amyloid plaques with $\mathrm{Cu}^{2+}$ can be substantiated, then the very high $\mathrm{Cu}^{2+}$ affinity of the abundant $\mathrm{A} \beta_{4-\mathrm{x}}$ isoform may provide a logical interpretation for such enrichment, since it has 3,000-fold higher affinity than $A \beta_{1-x}$ isoforms. One could argue hippocampal $A \beta_{4-42}$ contributes to $\mathrm{AD}$ due to the possibility this isoform can accumulate $\mathrm{Cu}^{2+}$, although $\mathrm{Cu}\left(\mathrm{A} \beta_{4-42}\right)$ does not appear capable of generating ROS. It is now established that endopeptidases such as NEP and IDE can hydrolyse the Glu3-Phe4 bond to generate $\mathrm{A} \beta_{4-\mathrm{x}}$ and there is a clear inverse correlation between in vivo NEP activity/levels and AD. In general agreement with an amyloid cascade hypothesis, a decline or impairment of $A \beta$-clearance mechanisms in age or $\mathrm{AD}$ may result in accumulation of $\mathrm{A} \beta_{1-42}$, leaving only the far $\mathrm{N}$-terminus accessible for cleavage yielding detectable post-mortem levels of $A \beta_{4-42}$ and increased levels of this peptide in $\mathrm{AD}$ hippocampus. Alternatively, if $A \beta_{4-42}$ or shorter, soluble and transient $A \beta_{4-x}$ proteolytic fragments have a functional role in copper homeostasis, any $\mathrm{Cu}^{2+}$ imbalance that might exist in $\mathrm{AD}$ or during aging could be associated with a downstream loss of function rather than a gain of toxic function. From this perspective, immunization strategies targeting both 
$\mathrm{A} \beta_{1-\mathrm{x}}$, and especially its $\mathrm{N}$-truncated isoform (Bayer and Wirths, 2014; Antonios et al., 2015), may perturb such putative function. Considering the relative affinities of $A \beta_{4-x}$ vs. $A \beta_{1-x}$ and that APP was proposed to be a $\mathrm{Cu}$ chaperone/transporter despite a modest affinity (apparent $K_{\mathrm{d}} \sim 10 \mathrm{nM}$ at $\mathrm{pH}$ 7) copper binding domain (Barnham et al., 2003b; Treiber et al., 2004; Kong et al., 2008), a comparable role for $A \beta_{4-x}$ is not unreasonable. While in vivo relevance remains speculative, the irony with respect to the metals hypothesis is that the brain might administer its own therapeutic chelator in the course of the normal catabolism of $\mathrm{A} \beta_{1-\mathrm{x}}$, and thus restoration of endoproteolytic processing could also restore copper homeostasis.

\section{REFERENCES}

Adlard, P. A., Bica, L., White, A. R., Nurjono, M., Filiz, G., Crouch, P. J., et al. (2011). Metal ionophore treatment restores dendritic spine density and synaptic protein levels in a mouse model of Alzheimer's disease. PLoS ONE 6:e17669. doi: 10.1371/journal.pone.0017669

Adlard, P. A., Cherny, R. A., Finkelstein, D. I., Gautier, E., Robb, E., Cortes, M., et al. (2008). Rapid restoration of cognition in Alzheimer's transgenic mice with 8-hydroxy quinoline analogs is associated with decreased interstitial $\mathrm{A} \beta$. Neuron 59, 43-55. doi: 10.1016/j.neuron.2008.06.018

Alies, B., Renaglia, E., Rózga, M., Bal, W., Faller, P., and Hureau, C. (2013). Cu(II) affinity for the Alzheimer's peptide: tyrosine fluorescence studies revisited. Anal. Chem. 85, 1501-1508. doi: 10.1021/ac302629u

Antonios, G., Borgers, H., Richard, B. C., Brauß, A., Meißner, J., Weggen, S., et al. (2015). Alzheimer therapy with an antibody against N-terminal Abeta 4-X and pyroglutamate Abeta 3-X. Sci. Rep. 5:17338. doi: 10.1038/srep17338

Atwood, C. S., Bowen, R. L., Smith, M. A., and Perry, G. (2003). Cerebrovascular requirement for sealant, anti-coagulant and remodeling molecules that allow for the maintenance of vascular integrity and blood supply. Brain Res. Rev. 43, 164-178. doi: 10.1016/S0165-0173(03)00206-6

Atwood, C. S., Moir, R. D., Huang, X., Scarpa, R. C., Bacarra, N. M., Romano, D. M., et al. (1998). Dramatic aggregation of Alzheimer abeta by $\mathrm{Cu}(\mathrm{II})$ is induced by conditions representing physiological acidosis. J. Biol. Chem. 273, 12817-12826. doi: 10.1074/jbc.273.21.12817

Atwood, C. S., Scarpa, R. C., Huang, X., Moir, R. D., Jones, W. D., Fairlie, D. P., et al. (2000). Characterization of copper interactions with Alzheimer amyloid $\beta$ peptides: identification of an attomolar-affinity copper binding site on amyloid $\beta_{1-42}$. J. Neurochem. 75, 1219-1233. doi: 10.1046/j.1471-4159.2000.0751219.x

Ayton, S., Lei, P., and Bush, A. I. (2013). Metallostasis in Alzheimer's disease. Free Radic. Biol. Med. 62, 76-89. doi: 10.1016/j.freeradbiomed.2012.10.558

Barnham, K. J., and Bush, A. I. (2014). Biological metals and metal-targeting compounds in major neurodegenerative diseases. Chem. Soc. Rev. 43, 6727-6749. doi: 10.1039/C4CS00138A

Barnham, K. J., Ciccotosto, G. D., Tickler, A. K., Ali, F. E., Smith, D. G., Williamson, N. A., et al. (2003a). Neurotoxic, redox-competent Alzheimer's $\beta$-amyloid is released from lipid membrane by methionine oxidation. J. Biol. Chem. 278, 42959-42965. doi: 10.1074/jbc.M305494200

Barnham, K. J., McKinstry, W. J., Multhaup, G., Galatis, D., Morton, C. J., Curtain, C. C., et al. (2003b). Structure of the Alzheimer's disease amyloid precursor protein copper binding domain. J. Biol. Chem. 278, 17401-17407. doi: 10.1074/jbc.M300629200

Barritt, J. D., and Viles, J. H. (2015). Truncated Amyloid- $\beta(11-40 / 42)$ from Alzheimer disease binds $\mathrm{Cu}^{2+}$ with a femtomolar affinity and influences fiber assembly. J. Biol. Chem. 290, 27791-27802. doi: 10.1074/jbc.M115.684084

Barrow, C. J., and Zagorski, M. G. (1991). Solution structures of beta peptide and its constituent fragments: relation to amyloid deposition. Science 253, 179-182. doi: $10.1126 /$ science. 1853202

Bayer, T. A., and Multhaup, G. (2005). Involvement of amyloid $\beta$ precursor protein $(\mathrm{A} \beta \mathrm{PP})$ modulated copper homeostasis in Alzheimer's disease. J. Alzheimer Dis. 8, 201-206. doi: 10.3233/jad-2005-8212

\section{AUTHOR CONTRIBUTIONS}

The author confirms being the sole contributor of this work and approved it for publication.

\section{ACKNOWLEDGMENTS}

The author was supported in part by a fellowship (FT110100199) administered by the Australian Research Council and a research fellowship awarded by the faculty of Medicine, Dentistry and Health Sciences, The University of Melbourne.

Bayer, T. A., and Wirths, O. (2014). Focusing the amyloid cascade hypothesis on $\mathrm{N}$-truncated Abeta peptides as drug targets against Alzheimer's disease. Acta Neuropathol. 127, 787-801. doi: 10.1007/s00401-014-1287-x

Behl, C., Davis, J. B., Lesley, R., and Schubert, D. (1994). Hydrogen peroxide mediates amyloid $\beta$ protein toxicity. Cell 77, 817-827. doi: 10.1016/0092-8674(94)90131-7

Behl, C., Davis, J., Cole, G. M., and Schubert, D. (1992). Vitamin E protects nerve cells from amyloid $\beta$ protein toxicity. Biochem. Biophys. Res. Commun. 186, 944-950. doi: 10.1016/0006-291X(92)90837-B

Blennow, K., Mattsson, N., Schöll, M., Hansson, O., and Zetterberg, H. (2015). Amyloid biomarkers in Alzheimer's disease. Trends Pharmacol. Sci. 36, 297-309. doi: 10.1016/j.tips.2015.03.002

Bourassa, M. W., and Miller, L. M. (2012). Metal imaging in neurodegenerative diseases. Metallomics 4, 721-738. doi: 10.1039/c2mt20052

Bouter, Y., Dietrich, K., Wittnam, J. L., Rezaei-Ghaleh, N., Pillot, T., PapotCouturier, S., et al. (2013). N-truncated amyloid $\beta$ (A $\beta$ ) 4-42 forms stable aggregates and induces acute and long-lasting behavioral deficits. Acta Neuropathol. 126, 189-205. doi: 10.1007/s00401-013-1129-2

Brewer, G. J. (2014). Alzheimer's disease causation by copper toxicity and treatment with zinc. Front. Aging Neurosci. 6:92. doi: 10.3389/fnagi.2014. 00092

Bush, A. I. (2000). Metals and neuroscience. Curr. Opin. Chem. Biol. 4, 184-191. doi: 10.1016/S1367-5931(99)00073-3

Bush, A. I. (2003). The metallobiology of Alzheimer's disease. Trends Neurosci. 26, 207-214. doi: 10.1016/S0166-2236(03)00067-5

Bush, A. I. (2008). Drug development based on the metals hypothesis of Alzheimer's disease. J. Alzheimers Dis. 15, 223-240. doi: 10.3233/JAD-2008-15208

Bush, A. I., and Tanzi, R. E. (2002). The galvanization of $\beta$-amyloid in Alzheimer's disease. Proc. Natl. Acad. Sci. U.S.A. 99, 7317-7319. doi: 10.1073/pnas.122249699

Bush, A. I., and Tanzi, R. E. (2008). Therapeutics for Alzheimer's disease based on the metal hypothesis. Neurotherapeutics 5, 421-432. doi: 10.1016/j.nurt.2008.05.001

Bush, A. I., Pettingell, W. H. Jr., Paradis, M. D., and Tanzi, R. E. (1994b). Modulation of $\mathrm{A} \beta$ adhesiveness and secretase site cleavage by zinc. J. Biol. Chem. 269, 12152-12158.

Bush, A. I., Pettingell, W. H., Multhaup, G., Paradis, M., Vonsattel, J. P., Gusella, J. F., et al. (1994a). Rapid induction of Alzheimer A $\beta$ amyloid formation by zinc. Science 265, 1464-1467.

Ceccom, J., Coslédan, F., Halley, H., Francès, B., Lassalle, J. M., and Meunier, B. (2012). Copper chelator induced efficient episodic memory recovery in a non-transgenic Alzheimer's mouse model. PLoS ONE 7:e43105. doi: 10.1371/journal.pone.0043105

Cherny, R. A., Atwood, C. S., Xilinas, M. E., Gray, D. N., Jones, W. D., McLean, C. A., et al. (2001). Treatment with a copper-zinc chelator markedly and rapidly inhibits $\beta$-amyloid accumulation in Alzheimer's disease transgenic mice. Neuron 30, 665-676. doi: 10.1016/S0896-6273(01)00317-8

Cherny, R. A., Legg, J. T., McLean, C. A., Fairlie, D. P., Huang, X., Atwood, C. S., et al. (1999). Aqueous dissolution of Alzheimer's disease A $\beta$ 
amyloid deposits by biometal depletion. J. Biol. Chem. 274, 23223-23228. doi: $10.1074 /$ jbc.274.33.23223

Chung, R. S., Howells, C., Eaton, E. D., Shabala, L., Zovo, K., Palumaa, P., et al. (2010). The native copper- and zinc- binding protein metallothionein blocks copper-mediated $\mathrm{A} \beta$ aggregation and toxicity in rat cortical neurons. PLoS ONE 5:e12030. doi: 10.1371/journal.pone.0012030

Ciccotosto, G. D., Tew, D., Curtain, C. C., Smith, D., Carrington, D., Masters, C. L., et al. (2004). Enhanced toxicity and cellular binding of a modified amyloid $\beta$ peptide with a methionine to valine substitution. J. Biol. Chem. 279, 42528-42534. doi: 10.1074/jbc.M406465200

Collins, S. J., Tumpach, C., Li, Q. X., Lewis, V., Ryan, T. M., Roberts, B., et al. (2015). The prion protein regulates $\beta$-amyloid mediated self-renewal of neural stem cells. Stem Cell Res. Therap. 6:60. doi: 10.1186/s13287-0150067-4

Crouch, P. J., Savva, M. S., Hung, L. W., Donnelly, P. S., Mot, A. I., Parker, S. J., et al. (2011). The Alzheimer's therapeutic PBT2 promotes amyloid- $\beta$ degradation and GSK3 phosphorylation via a metal chaperone activity. J. Neurochem. 119, 220-230. doi: 10.1111/j.1471-4159.2011.07402.x

Crouch, P. J., Tew, D. J., Du, T., Nguyen, D. N., Caragounis, A., Filiz, G., et al. (2009). Restored degradation of the Alzheimer's amyloid-beta peptide by targeting amyloid formation. J. Neurochem. 108, 1198-1207. doi: $10.1111 / j .1471-4159.2009 .05870 . x$

Curtain, C. C., Ali, F., Volitakis, I., Cherny, R. A., Norton, R. S., Beyreuther, $K$. ., et al. (2001). Alzheimer's disease Amyloid- $\beta$ binds copper and zinc to generate an allosterically ordered membrane-penetrating structure containing superoxide dismutase-like subunits. J. Biol. Chem. 276, 20466-20473. doi: 10.1074/jbc.M100175200

Danbolt, N. C. (2001). Glutamate uptake. Prog. Neurobiol. 65, 1-105. doi: 10.1016/S0301-0082(00)00067-8

Dawson, R. M. C., Elliott, D. C., Elliott, W. H., and Jones, K. M. (1990). Data for Biochemical Research, $3 r d$ Edn. Oxford: Clarendon Press.

Deibel, M. A., Ehmann, W. D., and Markesbery, W. R. (1996). Copper, iron, and zinc imbalances in severely degenerated brain regions in Alzheimer's disease: possible relation to oxidative stress. J. Neurol. Sci. 143, 137-142. doi: 10.1016/S0022-510X(96)00203-1

DeWitt, D. A., Perry, G., Cohen, M., Doller, C., and Silver, J. (1998). Astrocytes regulate microglial phagocytosis of senile plaque cores of Alzheimer's disease. Exp. Neurol. 149, 329-340. doi: 10.1006/exnr.1997.6738

Ding, W. Q., Liu, B., Vaught, J. L., Yamauchi, H., and Lind, S. E. (2005). Anticancer activity of the antibiotic clioquinol. Cancer Res. 65, 3389-3395. doi: 10.1158/0008-5472.CAN-04-3577

Dong, J., Atwood, C. S., Anderson, V. E., Siedlak, S. L., Smith, M. A., Perry, G., et al. (2003). Metal binding and oxidation of amyloid-beta within isolated senile plaque cores: Raman microscopic evidence. Biochemistry 42, 2768-2773. doi: 10.1021/bi0272151

Drew, S. C., and Barnham, K. J. (2011). The heterogeneous nature of $\mathrm{Cu}^{2+}$ interactions with Alzheimer's amyloid- $\beta$ peptide. Acc. Chem. Res. 44, 1146-1155. doi: 10.1021/ar200014u

Drummond, E., Nayak, S., Faustin, A., Pires, G., Hickman, R. A., Askenazi, M., et al. (2017). Proteomic differences in amyloid plaques in rapidly progressive and sporadic Alzheimer's disease. Acta Neuropathol. 133, 933-954. doi: 10.1007/s00401-017-1691-0

Duce, J. A., Bush, A. I., and Adlard, P. A. (2011). Role of amyloid$\beta$-metal interactions in Alzheimer's disease. Future Neurol. 6, 641-659. doi: $10.2217 /$ fnl.11.43

Duce, J. A., Tsatsanis, A., Cater, M. A., James, S. A., Robb, E., Wikhe, K., et al. (2010). Iron-export ferroxidase activity of $\beta$-amyloid precursor protein is inhibited by zinc in Alzheimer's disease. Cell 142, 857-867. doi: 10.1016/j.cell.2010.08.014

Ebrahimi, K. H., Dienemann, C., Hoefgen, S., Than, M. E., Hagedoorn, P. L., and Hagen, W. R. (2013). The amyloid precursor protein (APP) does not have a ferroxidase site in its E2 domain. PLoS ONE 8:e72177. doi: 10.1371/journal.pone.0072177

Ebrahimi, K. H., Hagedoorn, P. L., and Hagen, W. R. (2012). A synthetic peptide with the putative iron binding motif of amyloid precursor protein (APP) does not catalytically oxidize iron. PLOS ONE 7:e40287. doi: 10.1371/journal.pone.0040287
Eury, H., Bijani, C., Faller, P., and Hureau, C. (2011). Copper(II) coordination to amyloid $\beta$ : murine versus human peptide. Angew. Chem. Int. Ed. 50, 901-905. doi: 10.1002/anie.201005838

Faller, P., Hureau, C., and La Penna, G. (2014). Metal ions and intrinsically disordered proteins and peptides: from $\mathrm{Cu} / \mathrm{Zn}$ amyloid- $\beta$ to general principles. Acc. Chem. Res. 47, 2252-2259. doi: 10.1021/ar400293h

Faux, N. G., Ritchie, C. W., Gunn, A., Rembach, A., Tsatsanis, A., Bedo, J., et al. (2010). PBT2 rapidly improves cognition in Alzheimer's disease: additional phase II analyses. J. Alzheimer Dis. 20, 509-516. doi: 10.3233/JAD-201 $0-1390$

Frączyk, T., Zawisza, I. A., Goch, W., Stefaniak, E., Drew, S. C., and Bal, W. (2016). On the ability of $\mathrm{Cu}\left(\mathrm{A} \beta_{1-\mathrm{x}}\right)$ peptides to form ternary complexes: glutamate is not a ternary partner but may be a relevant competitor. J. Inorg. Biochem. 158, 30-34. doi: 10.1016/j.jinorgbio.2016.02.035

Gholz, L. M., and Arons, W. L. (1964). Prophylaxis and therapy of amebiasis and shigellosis with iodochlorhydroxyquin. Am. J. Trop. Med. Hyg. 13, 396-401. doi: $10.4269 /$ ajtmh.1964.13.396

Glenner, G. G., and Wong, C. W. (1984). Alzheimer's disease: initial report of the purification and characterization of a novel cerebrovascular amyloid protein. Biochem. Biophys. Res. Commun. 120, 885-890. doi: 10.1016/S0006-291X(84)80190-4

Goch, W., and Bal, W. (2017). Numerical simulations reveal randomness of $\mathrm{Cu}(\mathrm{II})$ induced $A \beta$ peptide dimerization under conditions present in glutamatergic synapses. PLoS ONE 12:e170749. doi: 10.1371/journal.pone.0170749

Gouras, G. K., and Beal, M. F. (2001). Metal chelator decreases Alzheimer $\beta$ amyloid plaques. Neuron 30, 641-647. doi: 10.1016/S0896-6273(01)00330-0

Grasso, G., Pietropaolo, A., Spoto, G., Pappalardo, G., Tundo, G. R., Ciaccio, C., et al. (2011). Copper(I) and copper(II) inhibit A $\beta$ peptides proteolysis by insulin-degrading enzyme differently: implications for metallostasis alteration in Alzheimer's disease. Chem. Eur. J. 17, 2752-2762. doi: 10.1002/chem.201002809

Haigh, C. L., Tumpach, C., Collins, S. J., and Drew, S. C. (2016). A 2-substituted 8hydroxyquinoline stimulates neural stem cell proliferation by modulating ROS signalling. Cell Biochem. Biophys. 74, 297-306. doi: 10.1007/s12013-016-0747-4

Hardy, J. A., and Higgins, G. A. (1992). Alzheimer's disease: the amyloid cascade hypothesis. Science 256, 184-185. doi: 10.1126/science.1566067

Hartter, D. E., and Barnea, A. (1998). Evidence for release of copper in the brain: depolarization-induced release of newly taken-up 67 copper. Synapse 2, 412-415. doi: 10.1002/syn.890020408

Hellström-Lindahl, E., Ravid, R., and Nordberg, A. (2008). Age-dependent decline of neprilysin in Alzheimer's disease and normal brain: inverse correlation with $\mathrm{A} \beta$ levels. Neurobiol. Aging 29, 210-221. doi: 10.1016/j.neurobiolaging.2006.10.010

Hensley, K., Carney, J. M., Mattson, M. P., Aksenova, M., Harris, M., Wu, J. F., et al. (1994). A model for beta-amyloid aggregation and neurotoxicity based on free radical generation by the peptide: relevance to Alzheimer disease. Proc. Natl. Acad. Sci. U.S.A. 91, 3270-3274. doi: 10.1073/pnas.91.8.3270

Herrup, K. (2015). The case for rejecting the amyloid cascade hypothesis. Nat. Neurosci. 18, 794-799. doi: 10.1038/nn.4017

Hoogenraad, T. U. (2011). Paradigm shift in treatment of Alzheimer's disease: zinc therapy now a conscientious choice for care of individual patients. Int. J. Alzheimer Dis. 2011:492686. doi: 10.4061/2011/492686

Howell, S., Nalbantoglu, J., and Crine, P. (1995). Neutral endopeptidase can hydrolyze $\beta$-amyloid(1-40) but shows no effect on $\beta$-amyloid precursor protein metabolism. Peptides 16, 647-652. doi: 10.1016/0196-9781(95)00021-B

Huang, X., Cuajungco, M. P., Atwood, C. S., Hartshorn, M. A., Tyndall, J. D., Hanson, G. R., et al. (1999). Cu(II) Potentiation of Alzheimer A $\beta$ Neurotoxicity. Correlation with cell-free hydrogen peroxide production and metal reduction. J. Biol. Chem. 274, 37111-37116. doi: 10.1074/jbc.274.52.37111

Hung, Y. H., Robb, E. L., Volitakis, I., Ho, M., Evin, G., Li, Q.-X., et al. (2011). Paradoxical condensation of copper with elevated beta-amyloid in lipid rafts under cellular copper deficiency conditions: implications for Alzheimer disease. J. Biol Chem. 284, 21899-21907. doi: 10.1074/jbc.M109.0 19521

Ingelsson, M., and Lannfelt, L. (eds.). (2016). Immunotherapy and biomarkers in neurodegenerative disorders, Methods in Pharmacology and Toxicology. New York, NY: Humana Press. 
Iwata, N., Tsubuki, S., Takaki, Y., Watanabe, K., Sekiguchi, M., Hosoki, E., et al. (2000). Identification of the major Abeta1-42-degrading catabolic pathway in brain parenchyma: suppression leads to biochemical and pathological deposition. Nat. Med. 6, 143-150. doi: 10.1038/72237

Jacobs, K. M., Bhave, S. R., Ferraro, D. J., Jaboin, J. J., Hallahan, D. E., and Thotala, D. (2012). GSK-3: a bifunctional role in cell death pathways. Int. J. Cell Biol. 2012:930710. doi: 10.1155/2012/930710

James, S. A., Churches, Q. I., de Jonge, M. D., Birchall, I. E., Streltsov, V., McColl, G., et al. (2017). Iron, copper, and zinc concentration in A $\beta$ plaques in the APP/PS1 mouse model of Alzheimer's disease correlates with metal levels in the surrounding neuropil. ACS Chem. Neurosci. 8, 629-637. doi: 10.1021 /acschemneuro.6b00362

James, S. A., Volitakis, I., Adlard, P. A., Duce, J. A., Masters, C. L., Cherny, R. A., et al. (2012). Elevated labile $\mathrm{Cu}$ is associated with oxidative pathology in Alzheimer disease. Free Radic. Biol. Med. 52, 298-302. doi: 10.1016/j.freeradbiomed.2011.10.446

Jenagaratnam, L., and McShane, R. (2006). Clioquinol for the treatment of Alzheimer's Disease. Cochrane Database Syst. Rev. CD005380. doi: 10.1002/14651858.CD005380.pub2

Jha, N. K., Jha, S. K., Kumar, D., Kejriwal, N., Sharma, R., Ambasta, R. K., et al. (2015). Impact of insulin degrading enzyme and neprilysin in Alzheimer's disease biology: characterization of putative cognates for therapeutic applications. J. Alzheimers Dis. 48, 891-897. doi: 10.3233/JAD-1 50379

Jiang, D., Zhang, L., Grant, G. P., Dudzik, C. G., Chen, S., Patel, S., et al. (2013). The elevated copper binding strength of amyloid- $\beta$ aggregates allows the sequestration of copper from albumin: a pathway to accumulation of copper in senile plaques. Biochemistry 52, 547-556. doi: 10.1021/bi301053h

Kalback, W., Watson, M. D., Kokjohn, T. A., Kuo, Y. M., Weiss, N., Luehrs, D. C., et al. (2002). APP transgenic mice $\operatorname{Tg} 2576$ accumulate $A \beta$ peptides that are distinct from the chemically modified and insoluble peptides deposited in Alzheimer's disease senile plaques. Biochemistry 41, 922-928. doi: 10.1021/bi015685

Kanemitsu, H., Tomiyama, T., and Mori, H. (2003). Human neprilysin is capable of degrading amyloid $\beta$ peptide not only in the monomeric form but also the pathological oligomeric form. Neurosci. Lett. 350, 113-116. doi: 10.1016/S0304-3940(03)00898-X

Kardos, J., Kovács, I., Hajós, F., Kálmán, M., and Simonyi, M. (1989). Nerve endings from rat brain tissue release copper upon depolarization. A possible role in regulating neuronal excitability. Neurosci. Lett. 103, 139-144. doi: 10.1016/0304-3940(89)90565-X

Kawamura, K., Kuroda, Y., Sogo, M., Fujimoto, M., Inui, T., and Mitsui, T. (2014). Superoxide dismutase as a target of clioquinol-induced neurotoxicity. Biochem. Biophys. Res. Commun. 452, 181-185. doi: 10.1016/j.bbrc.2014.04.067

Kenche, V. B., Zawisza, I., Masters, C. L., Bal, W., Barnham, K. J., and Drew, S. C. (2013). Mixed ligand $\mathrm{Cu}^{2+}$ complexes of a model therapeutic with Alzheimer's amyloid- $\beta$ peptide and monoamine neurotransmitters. Inorg. Chem. 52, 4303-4318. doi: 10.1021/ic302289r

Kepp, K. P. (2016). Alzheimer's disease due to loss of function: a new synthesis of the available data. Prog. Neurobiol. 143, 36-60. doi: 10.1016/j.pneurobio.2016.06.004

King, O. N., Li, X. S., Sakurai, M., Kawamura, A., Rose, N. R., Ng, S. S., et al. (2011). Quantitative high-throughput screening identifies 8hydroxyquinolines as cell-active histone demethylase inhibitors. PLOS ONE 5:e15535. doi: 10.1371/journal.pone.0015535

Klevay, L. M. (2008). Alzheimer's disease as copper deficiency. Med. Hypotheses 70, 802-807. doi: 10.1016/j.mehy.2007.04.051

Kong, G. K., Miles, L. A., Crespi, G. A., Morton, C. J., Ng, H. L., Barnham, K. J., et al. (2008). Copper binding to the Alzheimer's disease amyloid precursor protein. Eur. Biophys. J. 37, 269-279. doi: 10.1007/s00249-0070234-3

Krohn, M., Bracke, A., Avchalumov, Y., Schumacher, T., Hofrichter, J., Paarmann, K., et al. (2015). Accumulation of murine amyloid- $\beta$ mimics early Alzheimer's disease. Brain 138, 2370-2382. doi: 10.1093/brain/awv137

Kumar, D. K., Choi, S. H., Washicosky, K. J., Eimer, W. A., Tucker, S., Ghofrani, J., et al. (2016). Amyloid- $\beta$ peptide protects against microbial infection in mouse and worm models of Alzheimer's disease. Sci. Transl. Med. 8:340ra72. doi: $10.1126 /$ scitranslmed.aaf 1059
Lannfelt, L., Blennow, K., Zetterberg, H., Batsman, S., Ames, D., Harrison, J., et al. (2008). Safety, efficacy, and biomarker findings of PBT2 in targeting $\mathrm{A} \beta$ as a modifying therapy for Alzheimer's disease: a phase IIa, doubleblind, randomised, placebo-controlled trial. Lancet Neurol. 7, 779-786. doi: 10.1016/S1474-4422(08)70167-4

Leskovjan, A. C., Lanzirotti, A., and Miller, L. M. (2009). Amyloid plaques in PSAPP mice bind less metal than plaques in human Alzheimer's disease. Neuroimage 47, 1215-1220. doi: 10.1016/j.neuroimage.2009.05.063

Lewis, H., Beher, D., Cookson, N., Oakley, A., Piggott, M., Morris, C. M., et al. (2006). Quantification of Alzheimer pathology in ageing and dementia: age-related accumulation of amyloid- $\beta(42)$ peptide in vascular dementia Neuropathol. Appl. Neurobiol. 32, 103-118. doi: $10.1111 / j .1365-2990.2006 .00696 . x$

Lovell, M. A., Robertson, J. D., Teesdale, W. J., Campbell, J. L., and Markesbery, W. R. (1998). Copper, iron and zinc in Alzheimer's disease senile plaques. J. Neurol. Sci. 158, 47-52. doi: 10.1016/S0022-510X(98)00092-6

Lu, N., Yang, Q., Li, J., Tian, R., and Peng, Y. Y. (2015). Inhibitory effect of human serum albumin on $\mathrm{Cu}$-induced $\mathrm{A} \beta 40$ aggregation and toxicity. Eur. J. Pharmacol. 767, 160-164. doi: 10.1016/j.ejphar.2015.10.020

Lue, L. F., Kuo, Y. M., Roher, A. E., Brachova, L., Shen, Y., Sue, L., et al. (1999). Soluble amyloid $\beta$ peptide concentration as a predictor of synaptic change in Alzheimer's disease. Am. J. Pathol. 155, 853-862. doi: 10.1016/S0002-9440(10)65184-X

Madani, R., Poirier, R., Wolfer, D. P., Welzl, H., Groscurth, P., Lipp, H. P., et al. (2006). Lack of neprilysin suffices to generate murine amyloid-like deposits in the brain and behavioral deficit in vivo. J. Neurosci. Res. 84, 1871-1878. doi: $10.1002 / j n r .21074$

Manelli, A. M., and Puttfarcken, P. S. (1995). $\beta$-amyloid-induced toxicity in rat hippocampal cells: in vitro evidence for the involvement of free radicals. Brain Res. Bull. 38, 569-576. doi: 10.1016/0361-9230(95)02034-X

Martirosyan, A., Leonard, S., Shi, X., Griffith, B., Gannett, P., and Strobl, J. (2006). Actions of a histone deacetylase inhibitor NSC3852 (5-nitroso-8-quinolinol) link reactive oxygen species to cell differentiation and apoptosis in MCF7 human mammary tumor cells. J. Pharmacol. Exp. Ther. 317, 546-552. doi: 10.1124/jpet.105.096891

Masters, C. L., and Selkoe, D. J. (2012). Biochemistry of amyloid $\beta$-protein and amyloid deposits in Alzheimer disease. Cold Spring Harb. Perspect. Med. 2:a006262. doi: 10.1101/cshperspect.a006262

Masters, C. L., Multhaup, G., Simms, G., Pottgiesser, J., Martins, R. N., and Beyreuther, K. (1985a). Neuronal origin of a cerebral amyloid: neurofibriliary tangles of Alzheimer's disease contain the same protein as the amyloid of plaque cores and blood vessels. EMBO J. 4, 2757-2763.

Masters, C. L., Simms, G., Weinman, N. A., Multhaup, G., McDonald, B. L., and Beyreuther, K. (1985b). Amyloid plaque core protein in Alzheimer disease and Down syndrome. Proc. Natl. Acad. Sci. U.S.A. 82, 4245-4249. doi: 10.1073/pnas.82.12.4245

Mawuenyega, K. G., Sigurdson, W., Ovod, V., Munsell, L., Kasten, T., Morris, J. C. et al. (2010). Decreased clearance of CNS beta-amyloid in Alzheimer's disease. Science 330:1774. doi: 10.1126/science.1197623

Mayes, J., Tinker-Mill, C., Kolosov, O., Zhang, H., Tabner, B. J., and Allsop, D. (2014). $\beta$-amyloid fibrils in Alzheimer disease are not inert when bound to copper ions but can degrade hydrogen peroxide and generate reactive oxygen species. J. Biol. Chem. 289, 12052-12062. doi: 10.1074/jbc.M113.5 25212

Maynard, C. J., Cappai, R., Volitakis, I., Cherny, R. A., White, A. R., Beyreuther, K., et al. (2002). Overexpression of Alzheimer's disease amyloid-beta opposes the age-dependent elevations of brain copper and iron. J. Biol Chem. 277, 44670-44676. doi: 10.1074/jbc.M204379200

McLean, C. A., Cherny, R. A., Fraser, F. W., Fuller, S. J., Smith, M. J., Beyreuther, K., et al. (1999). Soluble pool of $A \beta$ amyloid as a determinant of severity of neurodegeneration. Ann. Neurol. 46, 860-866 doi: 10.1002/1531-8249(199912)46:6<860::AID-ANA8 > 3.0.CO;2-M

Meloni, G., Sonois, V., Delaine, T., Guilloreau, L., Gillet, A., and Teissié, J. (2008). Metal swap between Zn7-metallothionein-3 and amyloid- $\beta$ $\mathrm{Cu}$ protects against amyloid- $\beta$ toxicity. Nat. Chem. Biol. 4, 366-372. doi: $10.1038 /$ nchembio. 89

Miller, D. L., Papayannopoulos, I. A., Styles, J., Bobin, S. A., Lin, Y. Y., Biemann, K., et al. (1993). Peptide compositions of the cerebrovascular and senile plaque core 
amyloid deposits of Alzheimer's disease. Arch. Biochem. Biophys. 301, 41-52. doi: 10.1006/abbi.1993.1112

Miller, L. M., Wang, Q., Telivala, T. P., Smith, R. J., Lanzirotti, A., and Miklossy, J. (2006). Synchrotron-based infrared and X-ray imaging shows focalized accumulation of $\mathrm{Cu}$ and $\mathrm{Zn}$ co-localized with $\beta$-amyloid deposits in Alzheimer's disease. J. Struct. Biol. 155, 30-37. doi: 10.1016/j.jsb.2005.09.004

Mital, M., Wezynfeld, N. E., Fraczzyk, T., Wiloch, M. Z., Wawrzyniak, U. E., Bonna, A., et al. (2015). A functional role for $A \beta$ in metal homeostasis? $\mathrm{N}$-truncation and high-affinity copper binding. Angew. Chem. Int. Ed. 54, 10460-10464. doi: $10.1002 /$ anie. 201502644

Mital, M., Zawisza, I. A., Wiloch, M. Z., Wawrzyniak, U. E., Kenche, V., Wróblewski, W., et al. (2016). Copper exchange and redox activity of a prototypical 8-hydroxyquinoline-implications for therapeutic chelation. Inorg. Chem. 55, 7317-7319. doi: 10.1021/acs.inorgchem.6b00832

Miura, T., Suzuki, K., Kohata, N., and Takeuchi, H. (2000). Metal binding modes of Alzheimer's amyloid beta-peptide in insoluble aggregates and soluble complexes. Biochemistry 39, 7024-7031. doi: 10.1021/bi0002479

Mohajeri, M. H., Wollmer, M. A., and Nitsch, R. M. (2002). A $\beta 42$-induced increase in neprilysin is associated with prevention of amyloid plaque formation in vivo. J. Biol. Chem. 277, 35460-35465. doi: 10.1074/jbc.M202899200

Morelli, L., Llovera, R. E., Mathov, I., Lue, L. F., Frangione, B., Ghiso, J., et al. (2004). Insulin-degrading enzyme in brain microvessels. Proteolysis of amyloid vasculatropic variants and reduced activity in cerebral amyloid angiopathy. $J$. Biol. Chem. 279, 56004-56013. doi: 10.1074/jbc.M407283200

Näslund, J., Schierhorn, A., Hellman, U., Lannfelt, L., Roses, A. D., Tjernberg, L. O., et al. (1994). Relative abundance of Alzheimer $A \beta$ amyloid peptide variants in Alzheimer disease and normal aging. Proc. Natl. Acad. Sci. U.S.A. 91, 8378-8382. doi: 10.1073/pnas.91.18.8378

Ogra, Y., Tejima, A., Hatakeyama, N., Shiraiwa, M., Wu, S., Ishikawa, T., et al. (2016). Changes in intracellular copper concentration and copper-regulating gene expression after PC12 differentiation into neurons. Sci. Rep. 6:33007. doi: $10.1038 /$ srep 33007

Opazo, C., Huang, X., Cherny, R. A., Moir, R. D., Roher, A. E., White, A. R., et al. (2002). Metalloenzyme-like activity of Alzheimer's disease $\beta$-amyloid. $\mathrm{Cu}$-dependent catalytic conversion of dopamine, cholesterol, and biological reducing agents to neurotoxic $\mathrm{H}_{2} \mathrm{O}_{2}$. J. Biol. Chem. 277, 40302-40308. doi: $10.1074 /$ jbc.M206428200

Pedersen, J. T., Chen, S. W., Borg, C. B., Ness, S., Bahl, J. M., Heegaard, N. H., et al. (2016). Amyloid- $\beta$ and $\alpha$-synuclein decrease the level of metal-catalyzed reactive oxygen species by radical scavenging and redox silencing. J. Am. Chem. Soc. 138, 3966-3969. doi: 10.1021/jacs.5b13577

Perrone, L., Mothes, E., Vignes, M., Mockel, A., Figueroa, C., Miquel, M. C., et al. (2010). Copper transfer from $\mathrm{Cu}-\mathrm{A} \beta$ to human serum albumin inhibits aggregation, radical production and reduces $\mathrm{A} \beta$ toxicity. Chem. Bio. Chem. 11, 110-118. doi: 10.1002/cbic.200900474

Portelius, E., Bogdanovic, N., Gustavsson, M. K., Volkmann, I., Brinkmalm, G., Zetterberg, H., et al. (2010). Mass spectrometric characterization of brain amyloid beta isoform signatures in familial and sporadic Alzheimer's disease. Acta Neuropathol. 120, 185-193. doi: 10.1007/s00401-010-0690-1

Rajagopalan, R., Archilefu, S. I., Bugaj, J. E., and Dorshow, R. B. (2001). Quinoline Ligands and Metal Complexes for Diagnosis and Therapy. United States Patent No 6277841 B1.

Relkin, N. R. (2008). Testing the mettle of PBT2 for Alzheimer's disease. Lancet Neurol. 7, 762-763. doi: 10.1016/S1474-4422(08)70168-6

Rembach, A., Hare, D. J., Lind, M., Fowler, C. J., Cherny, R. A., McLean, C., et al. (2013). Decreased copper in Alzheimer's disease brain is predominantly in the soluble extractable fraction. Int. J. Alzheimers Dis. 2013:623241. doi: $10.1155 / 2013 / 623241$

Reybier, K., Ayala, S., Alies, B., Rodrigues, J. V., Bustos Rodriguez, S., La Penna, G., et al. (2016). Free superoxide is an intermediate in the production of $\mathrm{H}_{2} \mathrm{O}_{2}$ by copper(I)-A $\beta$ peptide and $\mathrm{O}_{2}$. Angew. Chem. Int. Ed. 55, 1085-1089. doi: 10.1002/anie.201508597

Robert, A., Liu, Y., Nguyen, M., and Meunier, B. (2015). Regulation of copper and iron homeostasis by metal chelators: a possible chemotherapy for Alzheimer's disease. Acc. Chem. Res. 48, 1332-1339. doi: 10.1021/acs.accounts.5b00119

Roberts, B. R., Ryan, T. M., Bush, A. I., Masters, C. L., and Duce, J. A. (2012). The role of metallobiology and amyloid- $\beta$ peptides in Alzheimer's disease. J. Neurochem. 120, 149-166. doi: 10.1111/j.1471-4159.2011.07500.x
Rosales-Corral, S., Acuna-Castroviejo, D., Tan, D. X., López-Armas, G., CruzRamos, J., Munoz, R., et al. (2012). Accumulation of exogenous amyloidbeta peptide in hippocampal mitochondria causes their dysfunction: a protective role for melatonin. Oxid. Med. Cell. Longev. 2012:843649. doi: $10.1155 / 2012 / 843649$

Rostagno, A., and Ghiso, J. (2009). Isolation and biochemical characterization of amyloid plaques and paired helical filaments. Curr. Protoc. Cell Biol. 44, 3.33:3.33.1-3.33.33. doi: 10.1002/0471143030.cb0333s44

Rottkamp, C. A., Raina, A. K., Zhu, X., Gaier, E., Bush, A. I., Atwood, C. S., et al. (2001). Redox-active iron mediates amyloid-beta toxicity. Free Radic. Biol. Med. 30, 447-450. doi: 10.1016/S0891-5849(00)00494-9

Rózga, M., and Bal, W. (2010). The $\mathrm{Cu}(\mathrm{II}) / \mathrm{A} \beta /$ human serum albumin model of control mechanism for copper-related amyloid neurotoxicity. Chem. Res. Toxicol. 23, 298-308. doi: 10.1021/tx900358j

Russo, R., Borghi, R., Markesbery, W., Tabaton, M., and Piccini, A. (2005). Neprylisin decreases uniformly in Alzheimer's disease and in normal aging. FEBS Lett. 579, 6027-6030. doi: 10.1016/j.febslet.2005.09.054

Ryan, T. M., Roberts, B. R., McColl, G., Hare, D. J., Doble, P. A., Li, Q.-X., et al. (2015). Stabilization of nontoxic $A \beta$-oligomers: insights into the mechanism of action of hydroxyquinolines in Alzheimer's disease. J. Neurosci. 35, 2871-2884. doi: 10.1523/JNEUROSCI.2912-14.2015

Saido, T., and Leissring, M. A. (2012). Proteolytic degradation of amyloid $\beta$-Protein. Cold Spring Harb. Perspect. Med. 2:a006379. doi: 10.1101/cshperspect.a006379

Sampson, E. L., Jenagaratnam, L., and McShane, R. (2008). Metal protein attenuating compounds for the treatment of Alzheimer's disease. Cochrane Database Syst. Rev. CD005380. doi: 10.1002/14651858.CD005380

Sampson, E. L., Jenagaratnam, L., and McShane, R. (2012). Metal protein attenuating compounds for the treatment of Alzheimer's dementia. Cochrane Database Syst. Rev. CD005380. doi: 10.1002/14651858.CD005380.pub4

Sampson, E. L., Jenagaratnam, L., and McShane, R. (2014). Metal protein attenuating compounds for the treatment of Alzheimer's dementia. Cochrane Database Syst. Rev. CD005380. doi: 10.1002/14651858.CD005380.pub5

Sarell, C. J., Wilkinson, S. R., and Viles, J. H. (2010). Substoichiometric levels of $\mathrm{Cu}^{2+}$ ions accelerate the kinetics of fiber formation and promote cell toxicity of amyloid- $\beta$ from Alzheimer disease. J. Biol. Chem. 285, 41533-41540. doi: $10.1074 /$ jbc.M110.171355

Schieb, H., Kratzin, H., Jahn, O., Möbius, W., Rabe, S., Staufenbiel, M., et al. (2011). Beta-amyloid peptide variants in brains and cerebrospinal fluid from amyloid precursor protein (APP) transgenic mice: comparison with human Alzheimer amyloid. J. Biol. Chem. 286, 33747-33758. doi: 10.1074/jbc.M111.246561

Schrag, M., Mueller, C., Oyoyo, U., Smith, M. A., and Kirsch, W. M. (2011). Iron, zinc and copper in the Alzheimer's disease brain: a quantitative metaanalysis. Some insight on the influence of citation bias on scientific opinion. Prog. Neurobiol. 94, 296-306. doi: 10.1016/j.pneurobio.2011.05.001

Schubert, D., and Chevion, M. (1995). The role of iron in beta amyloid toxicity. Biochem. Biophys. Res. Commun. 216, 702-707. doi: 10.1006/bbrc.1995.2678

Selkoe, D. J. (2008). Soluble oligomers of the amyloid $\beta$-protein impair synaptic plasticity and behaviour. Behav. Brain Res. 192, 106-113. doi: 10.1016/j.bbr.2008.02.016

Selkoe, D. J., Abraham, C. R., Podlisny, M. B., and Duffy, L. K. (1986). Isolation of low-molecular-weight proteins from amyloid plaque fibers in Alzheimer's disease. J. Neurochem. 46, 1820-1834. doi: 10.1111/j.1471-4159.1986.tb08501.x

Sergeant, N., Bombois, S., Ghestem, A., Drobecq, H., Kostanjevecki, V., Missiaen, C., et al. (2003). Truncated beta-amyloid peptide species in pre-clinical Alzheimer's disease as new targets for the vaccination approach. J. Neurochem. 85, 1581-1591. doi: 10.1046/j.1471-4159.2003.01818.x

Singh, I., Sagare, A. P., Coma, M., Perlmutter, D., Gelein, R., Bell, R. D., et al. (2013). Low levels of copper disrupt brain amyloid- $\beta$ homeostasis by altering its production and clearance. Proc. Natl. Acad. Sci. U.S.A. 110, 14771-14776. doi: $10.1073 /$ pnas. 1302212110

Smith, D. P., Smith, D. G., Curtain, C. C., Boas, J. F., Pilbrow, J. R., Ciccotosto, G. D., et al. (2006). Copper-mediated Amyloid- $\beta$ toxicity is associated with an intermolecular histidine bridge. J. Biol. Chem. 281, 15145-15154. doi: 10.1074/jbc.M600417200

Soscia, S. J., Kirby, J. E., Washicosky, K. J., Tucker, S. M., Ingelsson, M., Hyman, B., et al. (2010). The Alzheimer's disease-associated amyloid beta-protein is an antimicrobial peptide. PLoS ONE 5:e9505. doi: 10.1371/journal.pone.0009505 
Squitti, R. (2014). Copper subtype of Alzheimer's disease (AD): meta-analyses, genetic studies and predictive value of non-ceruloplasmin copper in mild cognitive impairment conversion to full AD. J. Trace Elem. Med. Biol. 28, 482-485. doi: 10.1016/j.jtemb.2014.06.018

Squitti, R., Ghidoni, R., Siotto, M., Ventriglia, M., Benussi, L., Paterlini, A., et al. (2014a). Value of serum nonceruloplasmin copper for prediction of mild cognitive impairment conversion to Alzheimer disease. Ann. Neurol. 75, 574-580. doi: 10.1002/ana.24136

Squitti, R., Rossini, P. M., Cassetta, E., Moffa, F., Pasqualetti, P., Cortesi, M., et al. (2002). D-penicillamine reduces serum oxidative stress in Alzheimer's disease patients. Eur. J. Clin. Invest. 32, 51-59. doi: 10.1046/j.1365-2362.2002.00933.x

Squitti, R., Siotto, M., and Polimanti, R. (2014b). Low-copper diet as a preventive strategy for Alzheimer's disease. Neurobiol. Aging 35(Suppl. 2), S40-S50. doi: 10.1016/j.neurobiolaging.2014.02.031

Stevenson, R. L., and Freiser, H. (1967). Tridentate ligands derived from substitution in the methyl group of 8-hydroxyquinaldine. Anal. Chem. 39, 1354-1358. doi: 10.1021/ac60256a013

Szabo, S. T. Harry, G. J., Hayden, K. M., Szabo, D. T., and Birnbaum, L. (2015). Comparison of metal levels between postmortem brain and ventricular fluid in Alzheimer's disease and nondemented elderly controls. Toxicol Sci. 150, 292-300. doi: 10.1093/toxsci/kfv325

Telpoukhovskaia, M. A., and Orvig, C. (2013). Werner coordination chemistry and neurodegeneration. Chem. Soc. Rev. 42, 1836-1846. doi: 10.1039/C2CS35236B

Tickler, A. K., Smith, D. G., Ciccotosto, G. D., Tew, D. J., Curtain, C. C., Carrington, D., et al. (2005). Methylation of the imidazole side chains of the Alzheimer disease amyloid- $\beta$ peptide results in abolition of superoxide dismutase-like structures and inhibition of neurotoxicity. J. Biol. Chem. 280, 13355-13363. doi: 10.1074/jbc.M414178200

Treiber, C., Simons, A., Strauss, M., Hafner, M., Cappai, R., Bayer, T. A., et al. (2004). Clioquinol mediates copper uptake and counteracts copper efflux activities of the amyloid precursor protein of Alzheimer's disease. J. Biol. Chem. 279, 51958-51964. doi: 10.1074/jbc.M407410200

Turnbull, S., Tabner, B. J., El-Agnaf, O. M., Twyman, L. J., and Allsop, D. (2001). New evidence that the Alzheimer beta-amyloid peptide does not spontaneously form free radicals: an ESR study using a series of spin-traps. Free Radic. Biol. Med. 30, 1154-1162. doi: 10.1016/S0891-5849(01)00510-X

Valensin, D., Migliorini, C., Valensin, G., Gaggelli, E., La Penna, G., Kozlowski, H., et al. (2011). Exploring the reactions of $\beta$-Amyloid $\left(\mathrm{A} \beta\right.$ ) peptide 1-28 with $\mathrm{Al}^{\mathrm{III}}$ and $\mathrm{Fe}^{\mathrm{III}}$ Ions. Inorg. Chem. 50, 6865-6867. doi: 10.1021/ic201069v

Vaughan, D. W., and Peters, A. (1981). The structure of neuritic plaques in the cerebral cortex of aged rats. J. Neuropathol. Exp. Neurol. 40, 472-487. doi: 10.1097/00005072-198107000-00009

Wang, H., Wang, M., Wang, B., Li, M., Chen, H., Yu, X., et al. (2012). The distribution profile and oxidation states of biometals in APP transgenic mouse brain: dyshomeostasis with age and as a function of the development of Alzheimer's disease. Metallomics 4, 289-296. doi: 10.1039/c2mt00104g

Watt, A. D., Perez, K. A., Rembach, A., Sherrat, N. A., Hung, L. W., Johanssen, T., et al. (2013). Oligomers, fact or artefact? SDS-PAGE induces dimerization of $\beta$-amyloid in human brain samples. Acta Neuropathol. 125, 549-564. doi: $10.1007 / \mathrm{s} 00401-013-1083-z$
Welzel, A. T., Maggio, J. E., Shankar, G. M., Walker, D. E., Ostaszewski, B. L., Li, S., et al. (2014). Secreted amyloid $\beta$-proteins in a cell culture model include Nterminally extended peptides that impair synaptic plasticity. Biochemistry 53 , 3908-3921. doi: 10.1021/bi5003053

Wezynfeld, N. E., Stefaniak, E., Stachucy, K., Drozd, A., Płonka, D., Drew, S. C., et al. (2016). Resistance of $\mathrm{Cu}(\mathrm{A} \beta 4-16)$ to copper capture by metallothionein3 supports a function of A $\beta 4-42$ peptide as synaptic $\mathrm{Cu}^{I I}$ scavenger, Angew. Chem. Int. Ed. 55, 8235-8238. doi: 10.1002/anie.201511968

White, A. R., Du, T., Laughton, K. M., Volitakis, I., Sharples, R. A., Xilinas, M. E., et al. (2006). Degradation of the Alzheimer disease amyloid $\beta$-peptide by metal-dependent up-regulation of metalloprotease activity. J. Biol. Chem. 281, 17670-17680. doi: 10.1074/jbc.M602487200

White, A. R., Reyes, R., Mercer, J. F., Camakaris, J., Zheng, H., Bush, A. I., et al. (1999). Copper levels are increased in the cerebral cortex and liver of APP and APLP2 knockout mice. Brain Res. 842, 439-444. doi: 10.1016/S0006-8993(99)01861-2

Whitson, J. S., Selkoe, D. J., and Cotman, C. W. (1989). Amyloid $\beta$ protein enhances the survival of hippocampal neurons in vitro. Science 243, 1488-1490. doi: $10.1126 /$ science. 2928783

Wiloch, M. Z. Wawrzyniak, U. E., Ufnalska, I., Bonna, A., Bal, W., Drew, S. C., et al. (2016). Tuning the redox properties of copper(II) complexes with amyloid- $\beta$ peptides. J. Electrochem. Soc. 163, G196-G199. doi: 10.1149/2.0641613jes

Wisniewski, T., and Goñi, F. (2014). Immunotherapy for Alzheimer's disease. Biochem. Pharmacol. 88, 499-507. doi: 10.1016/j.bcp.2013.12.020

Yankner, B. A., Duffy, L. K., and Kirschner, D. A. (1990). Neurotrophic and neurotoxic effects of amyloid beta protein: reversal by tachykinin neuropeptides. Science 250, 279-282. doi: 10.1126/science.2218531

Yasojima, K., Akiyama, H., McGeer, E. G., and McGeer, P. L. (2001). Reduced neprilysin in high plaque areas of Alzheimer brain: a possible relationship to deficient degradation of $\beta$-amyloid peptide. Neurosci. Lett. 297, 97-100. doi: 10.1016/S0304-3940(00)01675-X

Young, T. R., Kirchner, A., Wedd, A. G., and Xiao, Z. (2014). An integrated study of the affinities of the $\mathrm{Abl6}$ peptide for $\mathrm{Cu}(\mathrm{I})$ and $\mathrm{Cu}(\mathrm{II})$ : implications for the catalytic production of reactive oxygen species oxygen species. Metallomics 6 , 505-517. doi: 10.1039/C4MT00001C

Zhou, L., Wei, C., Huang, W., Bennett,. D. A., Dickson, D. W., Wang, R., et al. (2013). Distinct subcellular patterns of neprilysin protein and activity in the brains of Alzheimer's disease patients, transgenic mice and cultured human neuronal cells. Am. J. Transl. Res. 5, 608-621.

Conflict of Interest Statement: The author declares that the research was conducted in the absence of any commercial or financial relationships that could be construed as a potential conflict of interest.

Copyright ( 1017 Drew. This is an open-access article distributed under the terms of the Creative Commons Attribution License (CC BY). The use, distribution or reproduction in other forums is permitted, provided the original author(s) or licensor are credited and that the original publication in this journal is cited, in accordance with accepted academic practice. No use, distribution or reproduction is permitted which does not comply with these terms. 